\title{
National Presentations of Lower Mekong Sub-region Countries
}

Fidel R. Nemenzo, Masami Isoda, Maitree Inprasitha, Sampan Thinwiangthong, Narumon Changsri, Nisakorn Boonsena, Chan Roth, Monkolsery Lin, Souksomphone Anothay, Phoutsakhone Channgakham, Nguyen Chi Thanh, Vũ Như Thư Hương and Phương Thảo Nguyễn

\begin{abstract}
Mathematics educators have tried to take responsibility in improving the educational situations in the region. Among the countries in Lower Mekong sub-region, we have been able to gradually create collaboration through a network of a number of collaborative projects and study in mathematics education programs. The mathematics education community in this region was able to be established through the leading role played by Thailand in collaboration among the countries of the region. We should set long-term shared goals to solve the common problems in mathematics education and keep and expand the collaboration for better education in our Lower Mekong sub-region. The presentation consists of three parts: Overviews of (1) mathematics education in each country in the Lower Mekong sub-region (Cambodia, Laos, Myanmar, Thailand, and Vietnam), (2) the establishment of societies of mathematics education and development in each country, and (3) the emergent mathematics education community in the Lower Mekong sub-region.
\end{abstract}

\section{An Overview of Mathematics Education of Each Country in the Lower Mekong Sub-region}

In the first part, an overall summary of mathematics education of each country will be presented.

OECD and UNESCO studies have found that Thai teachers are not being prepared well in teacher education programs and lack nationwide continuing

\footnotetext{
F.R. Nemenzo

University of the Philippines, Manila, Philippines

e-mail: fidel@math.upd.edu.ph 
professional development. Moreover, half of the students are not acquiring basic skills in learning (OECD/UNESCO, 2016). In mathematics education in particular, teaching mathematics in Thailand for most teachers means preparing lesson plans by themselves, teaching those lesson plans in their closed classroom, checking the assigned homework, making some quizzes, and prescribing exercises (Inprasitha, 2003, 2015). Inprasitha (2003, 2016) has proposed a paradigm change in teaching approach from the traditional approach to be an open approach incorporating lesson study.

Mathematics education in Cambodia has many problems, for instance, a lack of well-qualified teachers and knowledge in curriculum development, textbook writing, use of Information and Communication Technology (ICT), and methodology of teaching (Roath, 2015). Most classes in schools are large, which are difficult for teachers control; however, the main cause of problems has been teachers' lack of effective methodology in teaching (International Mathematical Union, 2013).

Laos is also struggling in how to improve classroom teaching practice. Classroom observation has shown that the teachers' method involves lecturing and copying the lesson on the blackboard in the front of the classroom and asking questions, while students are passive learners, doing practical exercises (UNESCO, 2011). Laos also lacks continuous professional development and pre-service training (Benveniste et al., 2007). Laos is trying to improve its mathematics education; the goals of the mathematics curriculum education in Laos have been to ensure that students develop mathematical knowledge and skills that they can apply in other subjects and use in higher levels of study and have emphasized knowledge, skills, and attitudes (Thipmany, 2016).

General mathematics lessons in Vietnam involve most of class time for teaching the whole class, $90 \%$ for explaining and illustrating methods to the whole class, $8 \%$ for working individually, and $2 \%$ for working in groups. Reform of teaching methods in Vietnam started in 1992, with a focus on helping teachers to be aware of the need to improve teaching. The focus of the mathematics curriculum in 2000 was to provide students with basic applicable knowledge and skills for living in the community and for future study (Do, n.d.). Among the Lower Mekong sub-region countries, Vietnam does the best in mathematics education. The previous and most recent PISA results shows that Vietnam is in the top 10 of the 72 participating countries.

\section{Establishment of a Society of Mathematics Education and Development in Each Country}

This part describes the history of societies of mathematics education and their contributions in each country. This session reveals their roles and impacts on policies in their countries. Transformations of mathematics education will be described. 
The Cambodian Mathematical Society (CMS) was established on March 4, 2005, and recognized by the Royal Government of Cambodia. It plays a part in addressing the problems and improving the capacity of mathematics education in Cambodia as well as in the region. In 2013, the Thailand Society of Mathematics Education (TSMEd) was established by mathematics educators in Thailand and has organized an annual conference on mathematics education since 2013. In addition, the Center for Research on International Cooperation in Educational Development (CRICED) of the University of Tsukuba and the Center for Research in Mathematics Education (CRME) of the Faculty of Education, Khon Kaen University, have had a significant collaboration in creating the APEC Lesson Study project from 2006 until the present. This project has addressed the issue of innovations in mathematics teaching in the Asia-Pacific Economic Cooperation (APEC) member economies. The CRICED is a core center of Ministry of Education, Culture, Sports, Science and Technology (MEXT) that is jointly supported by Ministry of Foreign Affairs of Japan, while the CRME is supported and facilitated by Khon Kaen University and other related research funds in Thailand. In 2012, this collaborative work between Japan and Thailand was officially commended at the Fifth APEC Education Ministerial Meeting for supporting human-resource development focusing on developing in-service teachers using Japanese Lesson Study in 19 APEC economies.

Thailand will play an important role in education development in the countries in the Lower Mekong sub-region as a key region in Association of Southeast Asian Nations (ASEAN) community. A long-term collaboration between Thailand and Japan in contribution to mathematics education in this region is an example of education development in the subsequent ASEAN movement.

As the Lower Mekong sub-region is a strategic area for new economic development in the ASEAN community, mathematics is very important to support this development.

\section{Emergent Mathematics Education Communities in the Lower Mekong Sub-region}

The third part of the presentation discusses emergent mathematics education communities in the region. Collaboration across the countries is very important in order to improve the educational situations in the region. It provides the possibility of solving educational problems through networking and sharing and learning from each other.

The Faculty of Education at Khon Kaen University (KKU) in Thailand launched the Hoshino Project for training mathematics teachers in the Lao PDR since 2003. In the 2004 academic year, four trainees funded by the Education for Development Fund (EDF) Project studied in the master's degree program in the Department of Mathematics Education and Science Education at KKU. From 2005 to the present, 
the Department of Mathematics Education in the Faculty of Education at KKU has provided master's degree scholarships for 13 mathematics teachers from the Lao PDR through the EDF Project and the KKU-EDU Partnership Project (7 of the 13 have graduated and are working as network teachers and educators at KKU). From 2012 to the present, three bachelor's degree and three master's degree students from Cambodia received the Her Royal Highness Princess Maha Chakri Sirindhorn Scholarship to study in the mathematics education program at KKU. In this way, the mathematics education network across the countries has gradually been established by study in the mathematics education program at KKU.

In 2003, the Higher Education Commission ordered academic departments to create a cooperative research network $(\mathrm{CRN})$ in Thailand. Mathematics education was separated from the mathematics field and the Cooperative Research Network in Mathematics Education (CRN-MathEd) was created. The Faculty of Education at KKU started a master's degree program in mathematics education program and received a grant from the Project to Support the Competency for Competition of Thailand. This was the starting point for producing young mathematics educators in Thailand. From 2006 until the present, KKU and the University of Tsukuba have run the APEC Lesson Study Project. This project has contributed to the mathematics education community in Thailand. The work of this project since 2006 has contributed to the community through the book entitled Lesson Study: Challenging in Mathematics Education, edited by Maitree Inprasitha, Masami Isoda, Patsy Wang-Iverson, and Ban Har Yeap. The first two authors have been the overseers of the APEC Lesson Study since the beginning.

In 2007, the first group of graduate students participated and presented at the fourth East Asia Regional Conference on Mathematics Education (EARCOME 4) in Malaysia. In 2010, KKU graduate students joined EARCOME 5 in Japan. In 2013, Thailand was the host of EARCOME 6 and KKU provided the chance for Laotian and Cambodian teachers to join the conference. During the conference, the meeting for the Capacity and Networking Project (CANP) was organized by Bill Barton and colleagues and Maitree Inprasitha. The CANP is an international development project sponsored by the International Commission on Mathematical Instruction (ICMI) and the International Mathematical Union (IMU). The main aim of CANP3 is for participants from the different countries in Mekong area to work together and form a regional network in mathematics education and mathematics. This meeting led to the first CANP workshop in October 2013 in Cambodia. It engaged young mathematics educators from Cambodia, Laos, Thailand, and Vietnam as the trainees. In 2013, the Thailand Society of Mathematics Education was established by mathematics educators in Thailand, and it organized the first conference on mathematics education in January 2015 at KKU.

In May 2015, Thai mathematics educators and graduate students participated in EARCOME 7 in the Philippines. Graduate students from Cambodia, Laos, and Thailand were supported by a grant from ICMI and Bill Barton and Yeap Ban Har to join the conference and the second workshop of CANP during EARCOME 7. 
In June 2015, KKU provided a scholarship for Cambodian and Laotian graduate students to attend the ICMI Study 23 in Macau, China. During the ICMI Study 23, Ferdinando Arzarello, President of ICMI, arranged a meeting for CANP representatives and members from different regions, including some IPC members, to discuss forming a regional network in mathematics education and mathematics. In addition, in November 2015, Thailand had the great opportunity to host two joint international conferences, the World Association of Lesson Study (WALS) and 10th APEC Lesson Study International Symposium at KKU. We made every effort to involve participants from Vietnam and Myanmar in the conference and the third workshop of CANP.

In 2016, Lower Mekong sub-region countries developed and carried out several activities. Khon Kaen University shared ideas from the APEC Lesson Study Project with the Lower Mekong sub-region countries. We conducted the workshops in "Innovations on Teaching for Higher-Order Thinking in Mathematics for Teachers: Lesson Study and Open Approach" that were held June 13-14, 2016, at the National Institute of Education, Phnom Penh, Cambodia, and August 27-29, 2016, at Pakse Teacher Training College (Pakse TTC), Champasak Province, Lao PDR. In addition, the Institute for Research and Development on the Teaching Profession for ASEAN, KKU (IRDTP), and the National Center for Teachers' Development (NCTD) in Japan made an agreement to improve teacher professional development in Lower Mekong sub-region.

With efforts over the last 15 years, the Faculty of Education at KKU in Thailand has produced a number of mathematics educators and young mathematics educators who have to take responsibility for improving the educational situations in the region. Among the countries in Lower Mekong sub-region, we have been able to gradually create collaboration through a network of a number of collaborative projects and study in the mathematics education program at KKU. The mathematics education community in this region was established with Thailand playing the leading role in collaboration in the region. In October 2016, the Department of Teacher Education in the Lao PDR signed an memorandum of understanding (MOU) with Khon Kaen University to send five students to study in $\mathrm{PhD}$ programs, including mathematics education, for the next 10 years at KKU with the support of the Australian government through the Basic Education Quality and Access in Lao PDR (BEQUAL) project. We should set long-term shared goals to solve the common problems in mathematics education and keep and expand collaboration for better education in our Lower Mekong sub-region. Finally and hopefully, with the support of ICMI, the group of mathematics educators in this region might take on the challenge of hosting International Congress on Mathematical Education (ICME) in the next 12 or 16 years as Thailand took on the challenge of hosting EARCOME 6 in 2013. 


\section{References}

Benveniste, L., Marshall, J. \& Santibañez, L. (2007). Teaching in Lao PDR. Washington, DC: World Bank. https://openknowledge.worldbank.org/bitstream/handle/10986/7710/429710 ESW0LA0P10Box327342B01PUBLIC1.pdf?sequence=1\&isAllowed $=y$. Accessed January $21,2017$.

Do, Dat. (n.d.). Mathematics teaching and learning in Vietnam. http://www.ex.ac.uk/cimt/ijmtl/ ddvietmt.pdf. Accessed January 21, 2017.

Inprasitha, M. (2015). New model of teacher education program in mathematics education: Thailand experience. In Proceeding of 7th ICMI-East Asia Regional Conference on Mathematics Education (pp. 97-100).

Inprasitha, M. (2016). Research and development of modern mathematics instruction. $K K U$ : Research, 2, 2-9.

Inprasitha, M., et al. (2003). Reforming of the learning processes in school mathematics with emphasizing on mathematical processes. Khon Kaen Printing.

International Mathematical Union. (2013). Mathematics in Southeast Asia: Challenges and opportunities (Country Reports). http://www.mathunion.org/fileadmin/CDC/cdc-uploads/ CDC_MENAO/SEA_Reports.pdf. Accessed January 21, 2017.

OECD/ UNESCO. (2016). Education in Thailand: An OECD-UNESCO perspective, reviews of national policies for education. OECD Publishing. Paris. http://dx.doi.org/10.1787/ 9789264259119-en

Roath, C. (2015). Mathematics education in Cambodia from 1980 to 2012: Challenges and perspectives 2025. Journal of Modern Education Review, 5(12), 1147-1153.

Thipmany, O. (2016, February). National mathematics curriculum in Lao PDR. Paper presented at SEAMAO RECAM-University joint seminar: Searching for quality mathematics curriculum framework on the Era of Globalization. http://www.criced.tsukuba.ac.jp/math/apec/apec2016/ 20160216\%20Outhit\%20Math\%20CC\%20Development.pdf. Accessed January 21, 2017.

UNESCO. (2011). World data on education. http://www.ibe.unesco.org/sites/default/files/Lao_ PDR.pdf. Accessed January 21, 2017.

Open Access Except where otherwise noted, this chapter is licensed under a Creative Commons Attribution 4.0 International License. To view a copy of this license, visit http://creativecommons. org/licenses/by/4.0/.

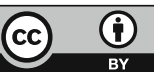

